\title{
仕様の相違が土壁の構造性能に及ぼす影響に関する実験的調査 INFLUENCE OF DIFFERENT SPECIFICATION OF MUD WALL ON STRUCTURE PERFORMANCE USING EXPERIMENTAL INVESTIGATION
}

\author{
岡 本滋史*, 村上 雅 英**, 稲山正弘*** \\ Shigefumi OKAMOTO, Masahide MURAKAMI and Masahiro INAYAMA
}

\begin{abstract}
The wall strength magnification ratio of mud wall of the defined specification was revised by the Ministry of Land, Infrastructure and Transport notification No. 1543 in 2004. The used material and the manufacture method for mud wall change with areas. While manufacture method and used material differ, the specifications of mud wall differ, which causes structure performance differ. In this paper, the various lathwork of mud wall and materials from mud of wall which are performed in various areas have been investigated. Based on investigated results the experimental variable of the lathwork of mud wall and use material have been determined. In order to predict the shear behavior of the mud wall in various manufacture states, tests on 129 different types of partial wall have been carried out.
\end{abstract}

Keywords : Japanese traditional structural system, Mud wall with uncovered posts and beams, Groundwork,Specification, Structural performance, Regionality 伝統構法，土壁真壁，下地，仕様，構造性能，地域性

\section{1..はじめに}

土壁の壁倍率は国土交通省告示第 1543 号により改正され、70mm 以上の塗厚の特定の仕様の両面塗りの土壁では 1.5 に引き上げられ た。告示の下地の組み方に関しては、三芳・大橋 ${ }^{1)}$ の実験によって 確認された仕様を基に定められているが、その根拠は 3 尺角試験体 と壁長が 1 間の耐力壁試験体による実験結果に基づいている。従って、 それらの試験体ではせん断破壊で最大耐力が決まっているものが多 く、仕様の違いによる検討は、せん断破壊を対象とした場合に限ら れることとなる。一方、土壁の破壊モードにはせん断破壊しない場 合も存在し、せん断破壊するか否かは壁長に依存することが、既往 の研究で抵抗機構に基づいた力学モデルにより説明できている ${ }^{4)}$ 。し かし、土壁は、地方によって施工方法や使用材料が多種多様にわた る上、下地の組み方などの仕様が異なる場合の土壁の破壞挙動、と りわけ破壞モードへ与える影響に関して不明な点が多い。そのため、 抵抗機構毎に仕様による影響を調心゙、力学モデルを用いて各破壊モ ードに対する影響を考察する方法が、根本的な解明につながり、合 理的な手法となる。

本研究 (本論文を含む一連の研究 $)^{2 / 334) 556)}$ では、土壁の構造性能評 価法を開発するため基䃈理論の構築を行った。(詳細は文献 6) に割 愛する）

\footnotetext{
* TE-DOK 工修

** 近畿大学理工学部建築学科 教授. 工博

*** 東京大学大学院農学生命科学研究科 准教授.工博
}

山田ら 7) は数值解析により壁土材料特性の土壁への影響を検討し ているが、土の圧縮性状の仮定のみを変えており、下地の違いなど は考慮されていない。そこで、本論文では、筆者らの今までの研究 成果 23344556) に基づき、力学モデルに基づいて土壁の抵抗機構を評価 するために開発された部分壁体試験体 5)6 を 用いて、全国各地で行わ れている様々な施工方法や使用材料の調査結果に基づき、使用材料 や下地の組み方など相違が土壁の各抵抗機構に対する影響を実験的 に調查することを目的とする。

\section{2. 土壁の仕様に関するアンケート調査と実験計画 \\ 2.1 アンケート調査}

全国各地で行われている様々な施工方法や使用材料を調查するた めに、インターネットで全国各地の土壁の施工を行っている工務店 を拾い出し、各工務店に電話で承諾を得てから調查表を FAX で送り 回答していただいた。その結果、新潟県、長野県、愛知県、滋賀県、 三重県、奈良県、愛媛県、福岡県の 9 件の工務店に調查にご協力い ただいた。アンケート調査の回答結果のまとめを表 1 に示す。また、 中尾ら ${ }^{8)}$ も全国の左官職人の 209 人に土壁の仕様に関するアンケー 卜調查を行っており、今回のアンケート調查と同じような結果を得 ている。
TE-DOK, M. Eng.

Prof., Dept. of Architecture, Graduate School of Science \& Engineering, Kinki Univ., Dr. Eng. Assoc. Prof., Graduate School of Agricultural and Life Sciences, The University of Tokyo, Dr. Eng. 
表 1 アンケート結果

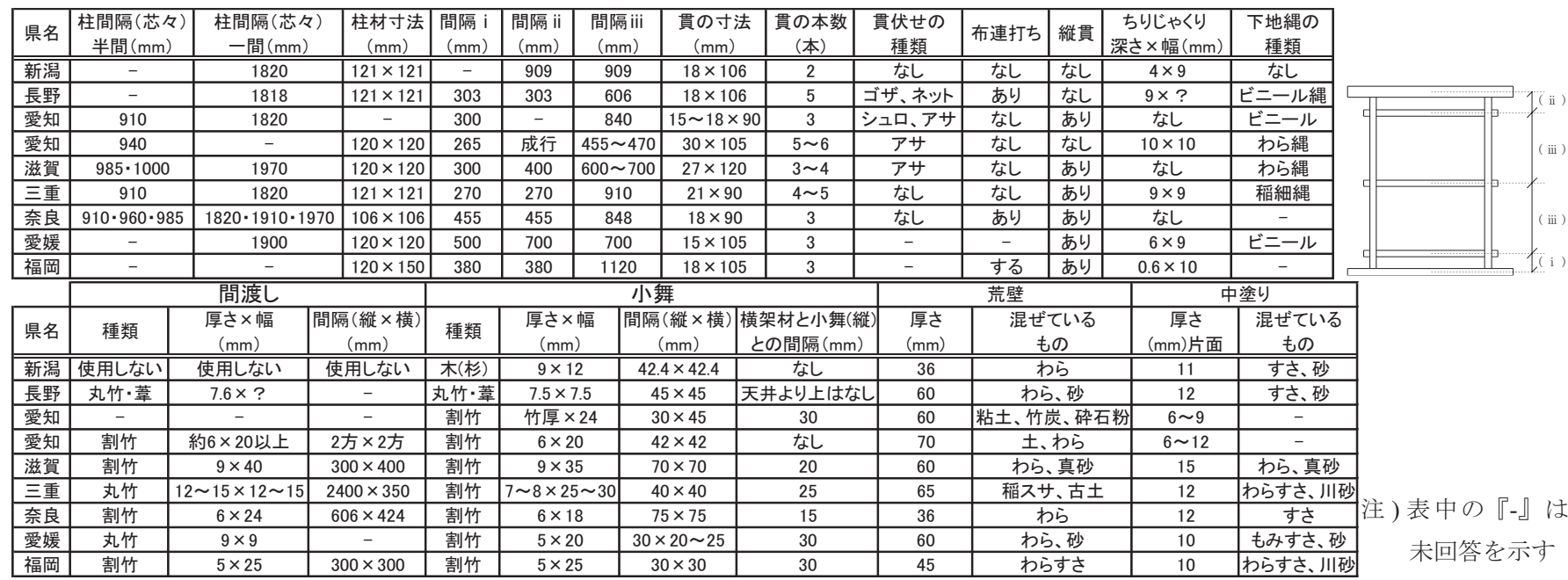

\section{2 土壁の仕様の考察と実験計画}

アンケート結果から下地の組み方の仕様を下記の様に考察し、仕 様の相違が土壁の構造性能に及ぼす影響を調べるための実験変数を 定めた。

小舞・間渡しの素材

小舞は近畿・中国・四国・九州等では基本的に割竹を使用してい るが、新潟・長野などでは木 (杉) ・丸竹・葦等が使用され、寒冷地 では竹の採取が困難であり、昔は木や莘が用いられていた名残であ る。間渡しは地方による偏りはみられず施工者によって異なってお り、近畿や四国でも丸竹が使用されていたり、壁厚によって割竹や 木 (杉) を使い分ける場合もある。実験変数として、小舞・間渡しの 素材が割竹・木 $($ 杉 $)$ ・ 丸竹・葦について検討する。本実験で使用し た割竹・木 $($ 杉) ・ 丸竹・莘を写真 1 に示す。

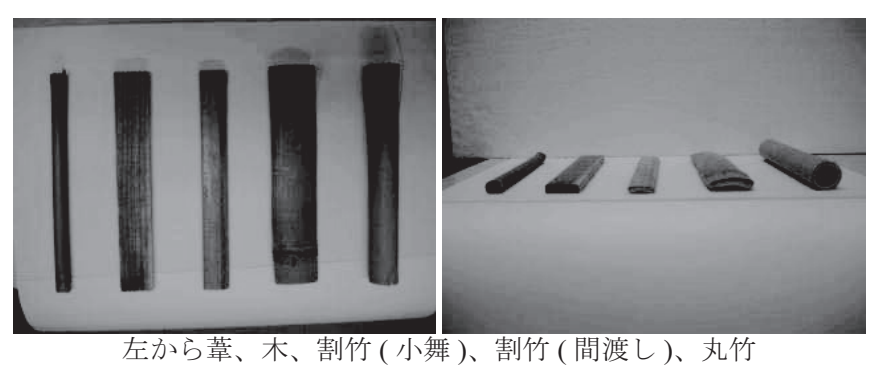

写真 1 小舞下地

\section{○舞・間渡しの幅 (直径)}

小舞の幅は施工者により異り、割竹は $10 \mathrm{~mm} \sim 30 \mathrm{~mm}$ 程度で使 用され、丸竹・葦は寸法にほとんど差異はみられず直径が $10 \mathrm{~mm}$ 前 後のものが多い。間渡しの幅も施工者により異り、割竹は $25 \mathrm{~mm} \sim$ 40mm、丸竹や葦は $10 \mathrm{~mm}$ 前後で使用されている。割竹や木 (杉) は 幅を調整できるが、丸竹や葦は加工せずにそのまま使われるので、 幅に関して差異が少ないと考えられる。実験変数として、割竹の小 舞の幅を $10 \mathrm{~mm} \cdot 20 \mathrm{~mm} ・ 30 \mathrm{~mm}$ にして検討する。

○小舞・間渡しの厚さ (直径)

小舞の厚さは $5 \mathrm{~mm} \sim 9 \mathrm{~mm}$ の間で、使用される竹の肉厚に依存し ている。間渡しの厚さあるいは直径は $5 \mathrm{~mm} \sim 12 \mathrm{~mm}$ の間で割り竹の 場合は小舞とほぼ同じ厚みである。厚みに関して大きな差異はない
が、丸竹の場合の間渡しの直径は小舞より少し大きめである。実験 変数として、厚さを変えやすい木小舞で厚さを $5 \mathrm{~mm}$ と $10 \mathrm{~mm}$ にして 検討する。

○舞と小舞の間隔

小舞と小舞の間隔は $30 \mathrm{~mm} \sim 75 \mathrm{~mm}$ と広範囲で施工されている。 これは小舞を編み込む過程での施工性で決まっていると考えられ、 アンケート結果からは小舞の種類や地域に関係なく、施工者によっ て差異が生じていると考えられる。実験変数として、小舞と小舞の 間隔を $40 \mathrm{~mm} \cdot 50 \mathrm{~mm} \cdot 60 \mathrm{~mm}$ にして検討する。

○一定量の小舞に対する小舞の幅

小舞の断面積比 (一定長さの壁断面積に対する小舞の断面積の比 ) が同じ場合の小舞の幅や間隔の関係が、力学性能に与える影響を調 ベる必要がある。そこで、実験変数として、小舞の断面積比を変え ずに小舞の幅・間隔を変えることによって、小舞を細く密に入れる 場合と太く疎に入れる場合について検討する。

○貫と貫の間隔

貫の段数は 3 本・ 5 本が多く、それらが標準的な仕様となっている。 2 本・4 本など特殊な例もみられるが、一般的ではない。そこで、貫 のこじり試験体と隅角部圧縮試験体の試験体寸法を実験変数として、 貫の本数が 3 本と 5 本について検討する。

\section{○地貫と横架材の間隔}

地貫と横架材の間隔は $260 \mathrm{~mm} \sim 500 \mathrm{~mm}$ で、ほとんどの地域で $300 \mathrm{~mm}$ 前後で使用されている。隅角部圧縮試験体の試験体寸法を実 験変数として、間隔の狭い場合 $(215 \mathrm{~mm})$ と広い場合 $(430 \mathrm{~mm})$ につい て検討する。

○壁土の塗り厚

荒壁は $36 \mathrm{~mm} \sim 70 \mathrm{~mm}$ で $60 \mathrm{~mm}$ 前後で塗られていることが多い。 また、中塗りは片面の塗り厚で $6 \mathrm{~mm} \sim 15 \mathrm{~mm}$ となっており、 $10 \mathrm{~mm}$ 前後で塗られていることが多い。荒壁と中塗りの厚みをあわせた全 体の厚みは $60 \mathrm{~mm} \sim 90 \mathrm{~mm}$ 程度となっている。実験変数として、荒 壁 $40 \mathrm{~mm}$ ・中塗り $15 \mathrm{~mm}$ ずつの壁厚 $70 \mathrm{~mm}$ と荒壁 $60 \mathrm{~mm}$ ・中塗り $15 \mathrm{~mm}$ ずつの壁厚 $90 \mathrm{~mm}$ にして検討する。

壁土の強度

壁土は各工務店の地域の付近で産出された土を使用していた。ま た、壁土の物性が産地により異なることから、荒壁・中塗りの調合 
は施工者によって異なっている。ここでは、構造的見地から壁土の 調合は研究対象とはせず、壁土に関しては圧縮強度のみで整理する こととする。実験変数として、地域の異なる荒木田・伏見・播磨の 3 種類の土を使用して検討する。特に播磨では、荒壁の上に中塗り を $5 \mathrm{~mm}$ ずつ塗った後に中塗り漆喰を $10 \mathrm{~mm}$ ずつ塗った。中塗り漆喰 とは、姫路城の修復に使用した中塗りに近い調合である白漆喰を混 ぜた強度の高い土である。播磨の土により強度の高い中塗りの影響 を調べる。

\section{3. 実験概要}

\section{1 検証用試験体}

アンケート結果を考察した実験変数に対して、文献 6) で提案をし た部分壁体試験体 (図 1) を用いて基準仕様の試験体から実験変数の
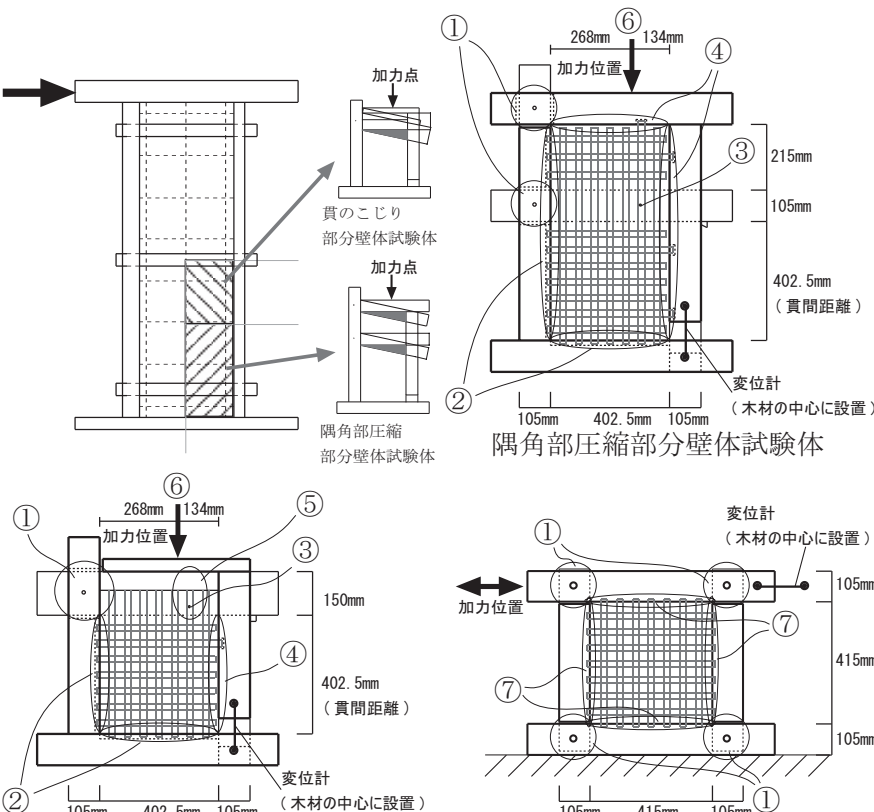

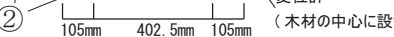
貫のこじり部分壁体試験体
仕様のみを変えた試験体を比較し、各種下地の影響を実験的に調べ る。部分壁体試験体は、隅角部での圧縮力による抵抗を評価するた めの『隅角部圧縮部分壁体試験体』、中央貫の土壁内での回転に対す る抵抗力を評価するための『貫のこじり部分壁体試験体』、中央貫の 土壁内での回転に対する抵抗力を評価するための『貫のこじり部分 壁体試験体』、土壁のせん断による抵抗力を評価するための『純せん 断部分壁体試験体』の 3 種類である。告示の仕様を基に定めた [基準] の試験体の仕様を表 2 に、[基準]の試験体の下地を組んだ軸組を写 真 2 に示寸。そして、[基準］に対して各実験変数のうち 1 つのみを 変化させて下地を組んだ試験体群を表 3 のように計画した。過去に 2 体ずつ行った京都仕様と秋田仕様 () の部分壁体試験結果 (図 2 と表 4) から、土壁の個体差が構造性能に及ぼす影響 ( ばらつき)をみて みると、隅角部圧縮部分壁体試験体から求めたモーメント一変形角 関係と純せん断部分壁体試験体から求 めた最大せん断応力度の試験体のばら つきは見られなかった。貫のこじり部 分壁体試験体では、荒壁の乾燥収縮の 度合により剛性が異なったが、最大耐 カ以降のモーメントー変形角関係の挙 動にばらつきは見られなかった。よっ て、図 2 で示した実験結果においては、 土壁の個体差が構造性能に及ぼす影響
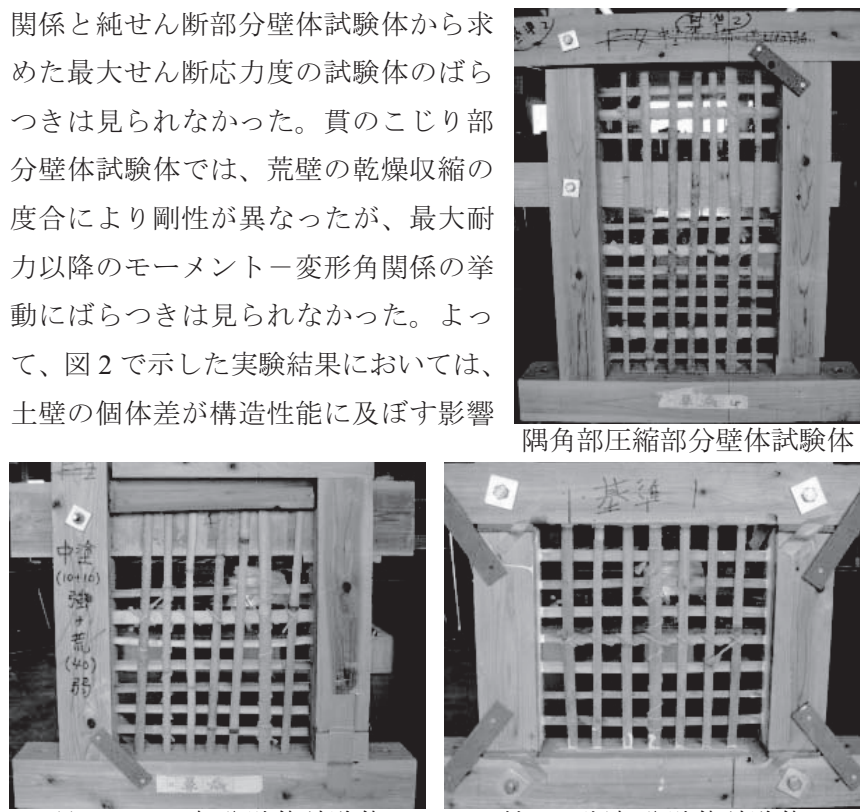

貫のこじり部分壁体試験体

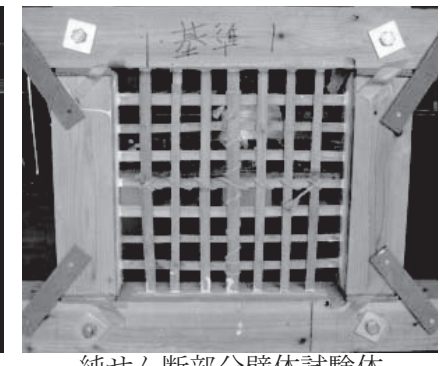

純せん断部分壁体試験体 写真 2 基準仕様試験体軸組

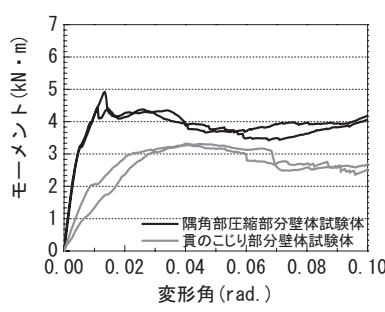

京都仕様試験体

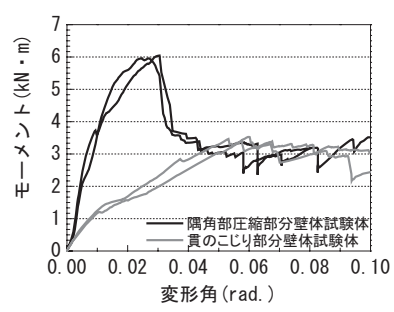

秋田仕様試験体 6)
図 2 部分壁体試験体による 1P 耐力壁の検証結果

1)仕口のピンと想定している部分では、想定変形角 1/7.5 rad 程度まて

軸組同士が接触しないように隙間を確保する。

土のる

(実際の耐力壁と同じように、間渡し竹は貫に釘打ちする。

(4)軸材と小舞竹との隙間は、実際の耐力壁と同じように空ける。

軸材に差し込む間渡し竹は、奏際の耐力壁と同じうに

想定変形角 $1 / 7.5 \mathrm{rad}$ 程度まで接触しないように隙間を確保する

図1 部分壁体試験体

\begin{tabular}{|c|c|}
\hline \multicolumn{2}{|c|}{ 基準仕梯 } \\
\hline 柱～柱 & $910 \mathrm{~mm}$ \\
\hline 土台～地貫 & $320 \mathrm{~mm}$ \\
\hline 地貫～中貫 & $910 \mathrm{~mm}$ \\
\hline 貫本数 & 3本 \\
\hline $\begin{array}{l}\text { 軸材の種類 } \\
\end{array}$ & 杉 \\
\hline 貫の種類 & 杉 \\
\hline 軸材の寸法 & $105 \times 105 \mathrm{~mm}$ \\
\hline 貫の寸法 & $15 \times 105 \mathrm{~mm}$ \\
\hline 小舞の種類 & 割竹 \\
\hline 小舞の寸法 & $20 \mathrm{~mm} \times 5 \mathrm{~mm}$ \\
\hline \begin{tabular}{l|} 
小舞間距離 \\
\end{tabular} & $50 \mathrm{~mm}$ \\
\hline 間渡しの種類 & 割竹 \\
\hline 間渡しの寸法 & $30 \mathrm{~mm} \times 5 \mathrm{~mm}$ \\
\hline 間渡L間距離 & $300 \mathrm{~mm}$ \\
\hline 荒壁厚さ & $40 \mathrm{~mm}$ \\
\hline 中塗り厚さ & 表裏 $15 \mathrm{~mm}$ ずつ \\
\hline 布連打万 & なし \\
\hline 貫伏せ & \\
\hline
\end{tabular}

表 3 試験体一覧

\begin{tabular}{|c|c|c|c|c|c|}
\hline \multicolumn{2}{|r|}{ 実験変数 } & 試験体名 & 隅角部 & 貫 & 純せん断 \\
\hline \multirow{6}{*}{ 小舞の種類 } & 木(厚さが $10 \mathrm{~mm})$ & A1 & 0 & $\mathrm{O}$ & 0 \\
\hline & 木(厚さ10mm)(すかしなし) & $\mathrm{A} 1^{\prime}$ & $\mathrm{O}$ & & \\
\hline & 丸竹 & $\mathrm{A} 2$ & $\mathrm{O}$ & $\mathrm{O}$ & $\mathrm{O}$ \\
\hline & 割竹(小舞)+丸竹(間渡し) & $\mathrm{A} 3$ & $\mathrm{O}$ & $\mathrm{O}$ & \\
\hline & 蔁3本(小舞)+丸竹(間渡し) & A4 & $\mathrm{O}$ & 0 & $\mathrm{O}$ \\
\hline & 蔁1本(小舞)+丸竹(間渡し) & A5 & $\mathrm{O}$ & & $\mathrm{O}$ \\
\hline \multirow{2}{*}{ 小舞の幅 } & 幅が $10 \mathrm{~mm}$ & $\mathrm{~B} 1$ & $\mathrm{O}$ & 0 & $\bar{O}$ \\
\hline & 幅が $30 \mathrm{~mm}$ & B2 & $\mathrm{O}$ & 0 & $\mathrm{O}$ \\
\hline \multirow{2}{*}{ 小舞の厚さ } & 木(厚さが $5 \mathrm{~mm})$ & $\mathrm{C} 1$ & $\mathrm{O}$ & $\mathrm{O}$ & $\mathrm{O}$ \\
\hline & 木(厚さ5mm)(すかしなし) & $\mathrm{C} 1^{\prime}$ & $\mathrm{O}$ & & \\
\hline \multirow{2}{*}{ 小舞の間隔 } & 間隔が $40 \mathrm{~mm}$ & D1 & $\mathrm{O}$ & $\mathrm{O}$ & $\mathrm{O}$ \\
\hline & 間隔が $60 \mathrm{~mm}$ & $\mathrm{D} 2$ & $\mathrm{O}$ & $\mathrm{O}$ & $\mathrm{O}$ \\
\hline 小舞の幅と間隔 & 幅が $10 \mathrm{~mm}$ 、間隔が $25 \mathrm{~mm}$ & E1 & $\mathrm{O}$ & 0 & $\mathrm{O}$ \\
\hline 貫間距離 & 貫5段相当の間隔 & F1 & $\mathrm{O}$ & $\mathrm{O}$ & \\
\hline 地貫と横架材の間隔 & 広い(貫板3枚程度) & G1 & $\mathrm{O}$ & $\mathrm{O}$ & \\
\hline 塗り厚が異なる壁体 & 中塗り $15 \mathrm{~mm}+15 \mathrm{~mm}$ 、荒壁 $60 \mathrm{~mm}$ & $\mathrm{H} 1$ & $\mathrm{O}$ & 0 & $\mathrm{O}$ \\
\hline
\end{tabular}

表 4 純せん断部分壁体試験

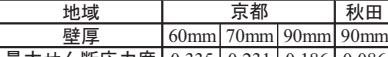

\begin{tabular}{lllllll}
\hline 最大せん断応力度 & 0.335 & 0.231 & 0.186 & 0.086 \\
\cline { 2 - 5 } & 0.352 & 0.231 & 0.188 & 0.087 \\
\hline
\end{tabular}

表 5 壁土の配合

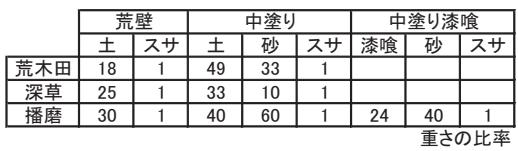


はあまりないと考えられる。これらのことから、土壁の個体差が構 造性能に及ぼす影響はあまりないと考えると、限られた予算内でこ れらの実験変数に対して、より多くの知見を得るために、壁土の種 類が異なっても各種下地の影響は同じように現れると仮定して、壁 土を 3 種類かえて、各実験変数に対して 1 体ずつ実験的調查を行う。 そして、各種下地の影響に関する比較は、同一の下地による 3 種類 の壁土の傾向から総合的に判断する。壁土は、荒木田・伏見・播磨 の 3 種類の土を使用して試験体を製作した。壁土の配合を表 4 に示 す。軸組に対して荒壁土を片面に塗り、4 日後にもう片面を塗った後、 およそ 3 週間乾燥させた後に中塗り土を塗った。そして、中塗り土 を塗った後は、1 月月ほど壁土を十分に乾燥し、実験を行った。検 討対象とした部分壁体試験体は各 1 体ずつの計 129 体である。比較 検証は土壁の抵抗要素による比較と耐力壁による比較で行う。抵抗 要素による比較は、部分壁体試験体ごとに軸組の耐力も考慮して行 う。耐力壁による比較は、文献 6)ですでに報告された方法で、部分 壁体試験体の試験結果から水平せん断力一変形角関係を推定して行 う。

\section{2 試験体、試験方法及び比較方法}

○隅角部圧縮部分壁体試験体・貫のこじり部分壁体試験体

実験は $100 \mathrm{kN}$ 万能試験機を用いて、加力点に球座を置いて一方向 単調加力で行った。計測は図 1 中の変位計測位置で行い、式(1), 式 (2) で求めたモーメントー変形角関係で各試験体の性能を評価して、 実験変数毎の比較を行う。

$\mathrm{M}=\mathrm{P} \times(268+105 / 2)(\mathrm{N} \cdot \mathrm{mm})$

$\mathrm{R}=\delta /(402.5+105)(\mathrm{rad})$

$\mathrm{P}:$ 部分壁体試験体の所定変形時荷重 $(\mathrm{N})$

$\delta$ : 部分壁体試験体の所定荷重時変位 $(\mathrm{mm})$

○純せん断部分壁体試験体

実験は繰り返し履歴がみかけの変形角 $1 / 600 、 1 / 450 、 1 / 300 、$ 1/200、1/150、1/100、1/75、1/50rad となるように各変位振幅で油圧 ジャッキにより正負 1 回繰り返し加力により行った。土台はボルト 2 本で試験装置に固定した。ボルトでピン接合とした軸組に小舞下 地を 1 本づつ穴に差し込み石膏で固定した。実験では、浮き上がり 変形を防止するためボルト間を金物でつないだ。計測は図 1 中の加 力位置 ( みかけの水平変位) と土壁表面の変位計測位置で行い、せん 断強度で各試験体の性能を評価して、実験変数毎の比較を行う。せ 几断強度は、実験で得られた最大せん断力 $\mathrm{Q}_{\text {max }}(\mathrm{N})$ を土壁の断面積 で除して算出した。

$\tau=\mathrm{Q}_{\max } /(415 \times \mathrm{t})\left(\mathrm{N} / \mathrm{mm}^{2}\right)$

$\mathrm{t}$ : 土壁の壁厚 $(\mathrm{mm})$

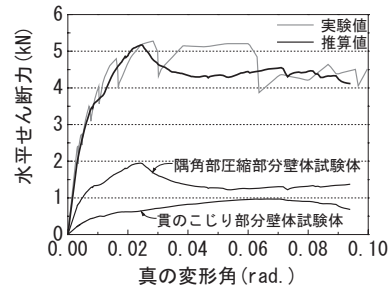

京都仕様試験体

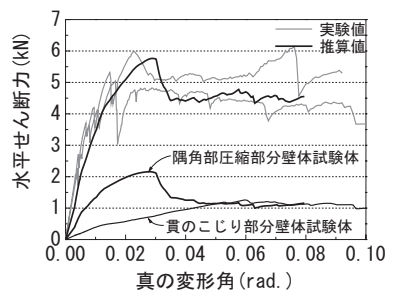

秋田仕様試験体
図 3 部分壁体試験体による 1P 耐力壁の検証結果 $\bigcirc 1 \mathrm{P}$ 耐力壁

$1 \mathrm{P}$ 耐力壁とは壁長が $910 \mathrm{~mm}$ の耐力壁のこ とで、1P 耐力壁の実験変数毎の比較は、文献 6)で検証した (図3に検証結果を示す)ように、 隅角部圧縮部分壁体試験体と貫のこじり部分 壁体試験体の試験結果から水平せん断力一変 形角関係を推定して行う。

\section{4. 壁土ブロック圧縮試験}

荒木田・伏見・播磨の 3 種類の土の圧縮強 度を調べるために、荒壁と中塗りの壁土ブロ ック $(200 \times 200 \times 60 \mathrm{~mm})$ を各 4 体づつ製作し、

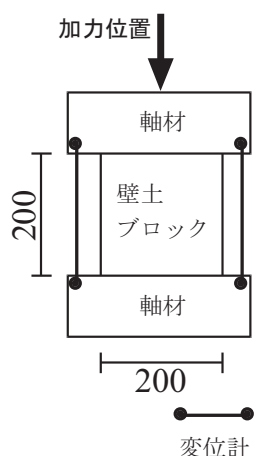

図 4 壁土ブロック

の圧縮試験 圧縮試験を行った。圧縮試験は図 4 に示すように上下を軸材ではさ み、石膏でキャッピングして加力した。壁土ブロックの圧縮試験結 果を図 5 に示す。荒壁では、伏見と播磨の剛性はほぼ同じであったが、 最大耐力に関しては伏見の方が低く、荒木田は伏見と播磨に比べ剛 性と最大耐力ともに低い結果となった。中塗りでは、3 種類とも荒 壁と比べて剛性と最大耐力が高く、播磨は荒木田・伏見よりも剛性 が約 2 倍程度あり、最大耐力時の縮夕量も $2 / 3$ 程度小さい結果とな った。

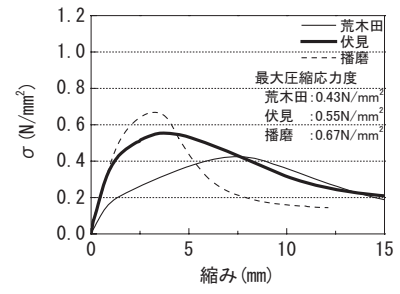

荒壁

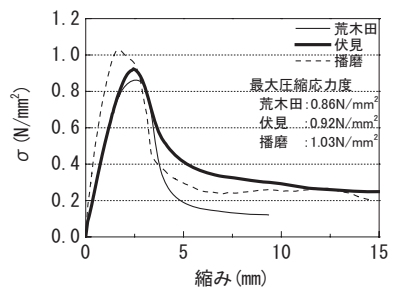

中塗り
図 5 壁土ブロックの圧縮試験結果 (平均值)

\section{5. 隅角部圧縮部分壁体試験体}

5.1 試験体の破壊状況

試験体の破壊状況を写真 3 に示す。破壞モードは 2 種類あり、横 架材の圧縮によって隅角部の土壁が圧壊し、横架材付近から貫下に 至るまで小舞や間渡しが座屈して、壁土が面外に押し出されて壁体 全体で剥離する破壊 (破壊 a) と、貫付近を中心として小舞と間渡し が座屈して、壁土が面外に押し出されて貫付近の壁土が剥離する破 壊 ( 破壊 b) が確認された。また、破壊状況から最大耐力後の耐力低 下は、小舞や間渡しの座屈で始まるため、小舞や間渡しの座屈耐力

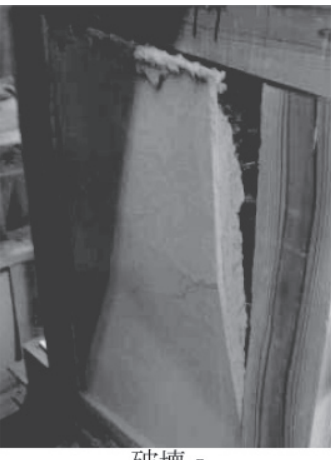

破壊 a

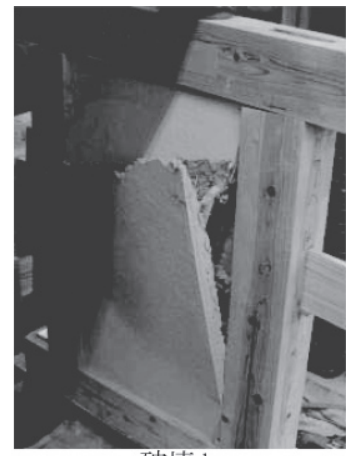

破壊 b
写真 3 隅角部圧縮部分壁体試験体の破壊状況 
が隅角部圧縮部分壁体試験体の 最大耐力に影響をおよぼすと推 測される。

\section{2 試験結果の比較}

下地を同一として 3 種類の壁 土の違いのみで比較した [基準 $]$ の試験結果を図 6 に示す。変形 角が $0.01 \mathrm{rad}$ 付近までを比較し
図 6 隅角部圧縮部分壁体試験結 果［基準］(壁土比較)

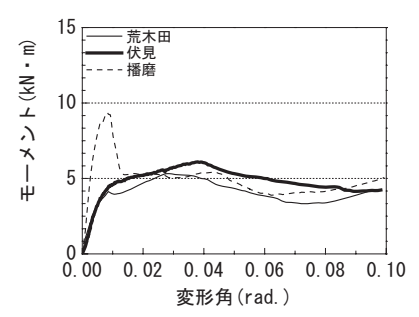

てみると、［伏見］と［荒木田］は同じょうなモーメントー変形角関 係を示し、[播磨］は耐力が高かった。これは、主に隅角部の壁土 の圧縮抵抗が支配的であり、中塗りの剛性が［伏見］と［荒木田］ に比べて[播磨］は約 2 倍高かったことに起因すると考えられる。 $0.01 \mathrm{rad}$ 以降、[伏見］と［荒木田］は剛性が低下し、[播磨］は耐力 が低下した。0.01 rad 以降の変形角で比較してみると、［伏見］と［播 磨］は同じようなモーメントー変形角関係を示し、[荒木田］のみ若 干耐力が低かった。文献 3) の『比較実験』で得られた各耐力要素の 負担割合の推移 (図 7) によると、0.01 rad 付近までは隅角部の圧縮抵 抗が支配的であるが、0.01 rad 以降では貫のこじり抵抗が支配的であ ることがわかる。これは、土壁の隅角部において変形が進むと、大 変形時には図 8 の様に小舞竹が面外一座屈して、壁土が厚み方向へ 膨らみ、横架材に直接土壁から作用寸る圧縮抵抗力は低下し、貫の こじり抵抗が支配的となり、その時の抵抗要素は主として荒壁であ る。したがって、荒壁の耐力が［伏見］と［播磨］に比べて［荒木田］ は若干低かったため隅角部圧縮部分壁体試験体においても [荒木田]

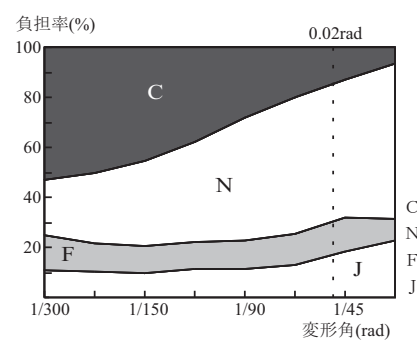

図 7 各耐力要素の負担割合の推移

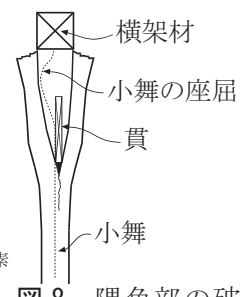

図 8 隅角部の破 壊状況

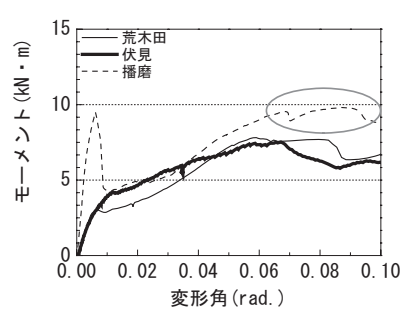

A2

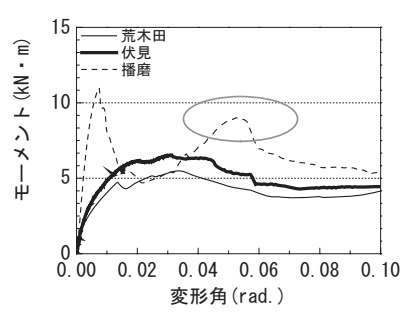

$\mathrm{D} 2$

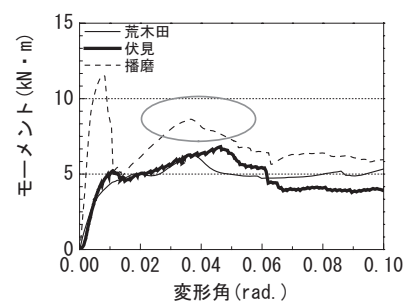

B2

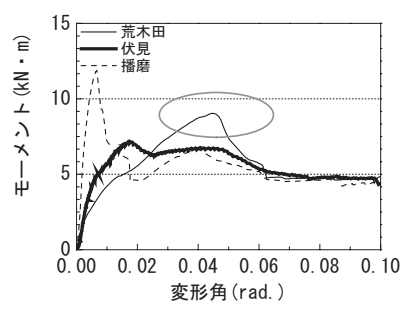

$\mathrm{H} 2$
図 9 隅角部圧縮部分壁体試験結果 (挙動が異なった試験体)
の大変形時の耐力が低くなったと考えられる。図 9 に示す［荒木田］ の $\mathrm{H} 1$ 、[播磨］の $\mathrm{A} 2 \cdot \mathrm{B} 2 \cdot \mathrm{D} 2$ のみ。印で囲った部分が他の壁土の 場合と異なる挙動を示したが、それぞれの実験変数において、他の 2 種類の壁土では同じような傾向となっている。したがって、これ らの試験体のみ下地の座屈が他の試験体と比べて遅れたため、耐力 が高くなり挙動が異なったと思われる。しかしながら、これら以外 の寸べての試験体では、下地の仕様毎に 3 種類の壁土で比較してみ ても、図 6 に示寸 [基準]の試験結果と同じような傾向となった。 このことより、0.01 rad 付近までは主に壁土 (特に中塗り)の圧縮抵
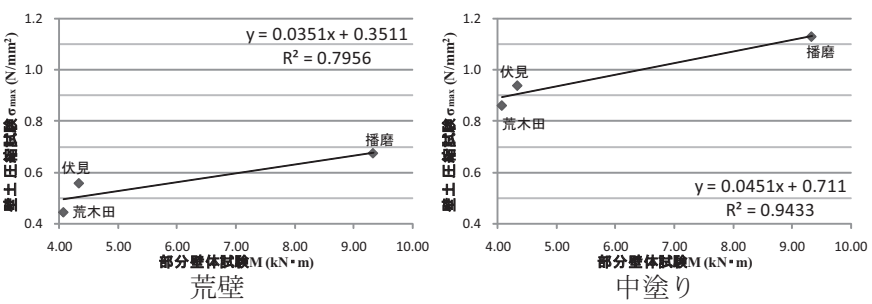

図 10 隅角部圧縮部分壁体試験［基準］の 1/120rad 時の耐力と壁土強 度の関係

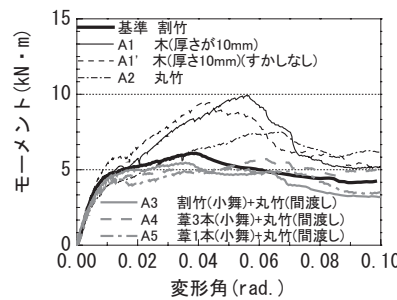

小舞の種類 $[\mathrm{A}]$

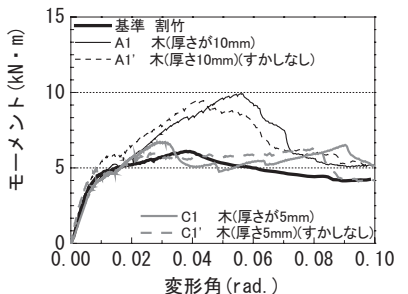

小舞の厚さ $[\mathrm{C}]$

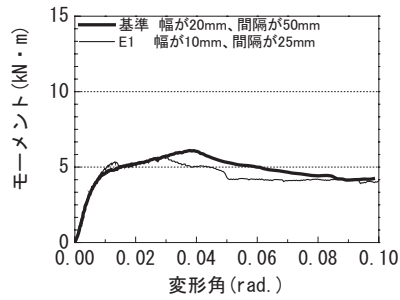

小舞の幅と間隔 $[\mathrm{E}]$

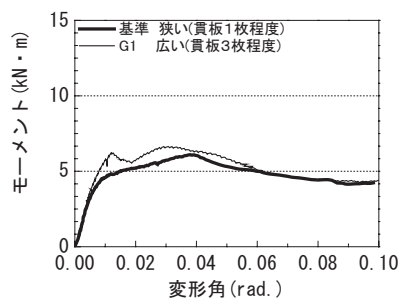

地貫と横架材の間隔 $[\mathrm{G}]$

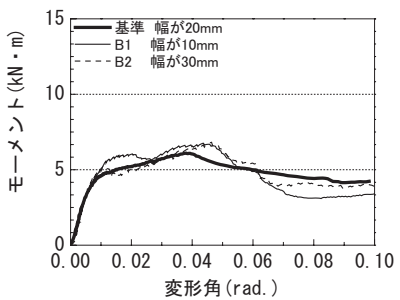

小舞の幅 $[\mathrm{B}]$

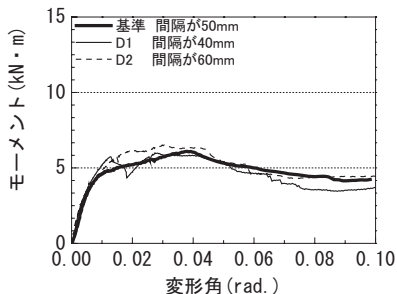

小舞の間隔 $[\mathrm{D}]$

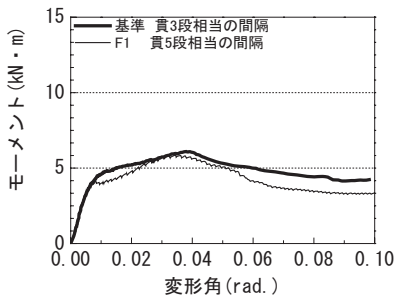

貫間距離 $[\mathrm{F}]$

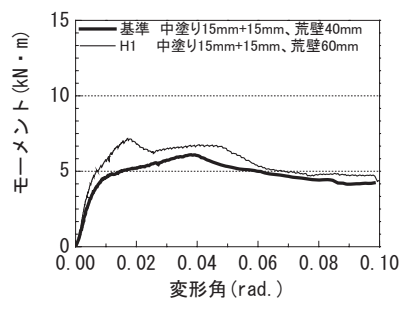

塗り厚が異なる壁体 $[\mathrm{H}]$
図 11 隅角部圧縮部分壁体試験結果［伏見］(下地比較) 


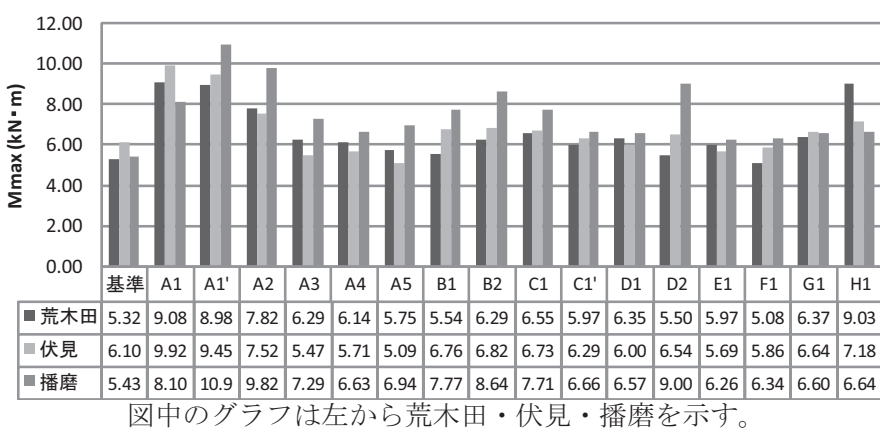

図 12 隅角部圧縮部分壁体試験結果の $0.01 \mathrm{rad}$ 以降の耐力の最大值の比 較

抗により耐力が増加したが、0.01 $\mathrm{rad}$ 付近で壁土が圧壊したため、壁 土の圧縮抵抗が減少することによって耐力が低下して、0.01 rad 以降 では主として間渡しや小舞による下地の圧縮力で抵抗していると考 えられる。[基準］の 1/120 $\operatorname{rad}$ (播磨の最大耐力時の変形角) の耐力 と壁土の圧縮強度の関係を図 10 に示寸。相関係数 (図 10 の R) から、 隅角部の圧縮抵抗は荒壁よりも中塗りの方が耐力発現に寄与してい るといえる。

壁土を同一として下地の違いのみで比較した [伏見］の試験結果 を図 11 に、隅角部が間渡しや小舞による下地の圧縮抵抗のみで抵抗 していると考えられる $0.01 \mathrm{rad}$ 以降の最大耐力の比較を図 12 に示す。 小舞の種類 [A] では、0.01 rad 付近までは主に壁土 (特に中塗り)の 圧縮抵抗により耐力が増加したため耐力の差は見られなかったが、 $0.01 \mathrm{rad}$ 以降では蔁 (1 本) $[\mathrm{A} 5] \rightarrow$ 葦 $(3$ 本) $[\mathrm{A} 4] \rightarrow$ 割竹 [基準 $]$ $\rightarrow$ 丸竹 $[\mathrm{A} 2] \rightarrow$ 木 (厚さ $10 \mathrm{~mm}$ ) [A1］の順で耐力が高い結果とな った。また、小舞の厚さ $[\mathrm{C}]$ では、木 (厚さ $5 \mathrm{~mm})[\mathrm{Cl}$ ］＜wide>木（厚 さ $10 \mathrm{~mm})[\mathrm{A} 1 ］$ の順で耐力が高い結果となった。[A1］と［A1］及 び $[\mathrm{C} 1]$ と $\left[\mathrm{Cl}^{\prime}\right]$ の比較による小舞下地と軸組とのすかし( 軸組と 小舞との $10 \mathrm{~mm}$ の隙間) の有無では、耐力の差はほとんど見られな

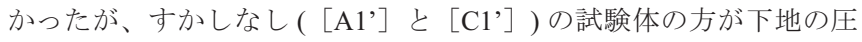
縮抵抗による耐力発現が早く現われた。間渡しの仕様が同じで小舞 の仕様のみが異なる実験変数 (小舞の幅 $[\mathrm{B}]$, 小舞の間隔 $[\mathrm{D}]$, 小 舞の幅と間隔 $[\mathrm{E} ］$ ) では、[基準］と同じようなモーメントー変形 角関係を示し、[基準］に対する強度の差は見られなかったことから、 $0.01 \mathrm{rad}$ 以降の下地の圧縮抵抗は間渡しの強度負担の割合が高いと考 えることができる。その理由は、間渡しは小舞を編むための骨格と なるものであり、軸組に対して大入れで固定されており、小舞は軸 組と $10 \mathrm{~mm}$ 程度の隙間を設けて編んであり (図 1 中のすかし)、間渡 しが小舞より先に圧縮力を負担するためである。貫間距離 $[\mathrm{F}]$ では、

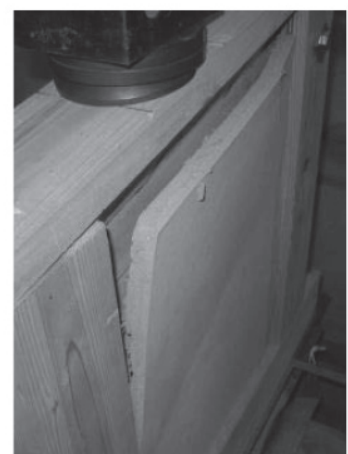

写真 4 貫のこじり部分壁体試験 図 13 体の破壊状況

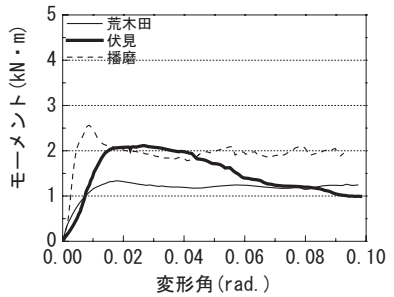

貫のこじり部分壁体試験 結果 [基準］(壁土比較)
［基準］と同じようなモーメントー変形角関係を示し、［基準］に対 する強度の差はほとんど見られなかった。地貫と横架材の間隔 [G] では、貫と横架材の間隔が広いと貫のこじりの破壊が隅角部の破壊 に繋がることによるお互いの破壊による影響が少なく、大変形時ま で耐力がやや高くなった。塗り厚が異なる壁体 $[\mathrm{H}]$ では、壁土の 隅角部の圧縮抵抗力は壁厚に比例して大きくなるため、大変形時ま で耐力が高くなった。[荒木田］と［播磨］に関しても、変形角が $0.01 \mathrm{rad}$ 付近まではそれぞれ図 6 の［基準］と同じような挙動となり、 変形角が $0.01 \mathrm{rad}$ 以降になると 3 種類の壁土の違いによる強度の差は 見られず、図 11 の [伏見］と同じような挙動となった。

これらのことより、隅角部の圧縮抵抗は、0.01 rad 付近までは主と して壁土の圧縮抵抗により、0.01 rad 以降は主として下地の圧縮抵抗 により生じていると判断できる。また、0.01 rad 以降の下地の圧縮抵 抗では、間渡しの強度負担の割合が高いと推測される。

\section{6. 貫のこじり部分壁体試験体}

\section{1 試験体の破壊状況}

試験体の破壊状況を写真 4 に示す。破壊モードは、貫が小舞に沿 って荒壁を裂くように回転しながら下がり、貫が通った部分の壁土 が剥離する破壊であり、荒壁の圧縮強度が貫のこじり部分壁体の最 大耐力に影響を及ぼすと推測される。

\section{2 試験結果の比較}

下地を同一として 3 種類の壁土の違いのみで比較した［基準］の 試験結果を図 13 に示す。荒壁の乾燥収縮により貫と荒壁との間に隙 間ができるため、初期変形時では荒壁の乾燥収縮の度合により初期 すべり量が異なった。最大耐力は、荒壁の圧縮強度と同じような耐 力の差となり、荒木田 $\rightarrow$ 伏見 $\rightarrow$ 播磨の順で高い結果となった。また、 0.02 $\mathrm{rad}$ までの［播磨］の耐力は［伏見］と［荒木田］に比べて隅角 部圧縮部分壁体試験ほど高くなかった。［基準］の最大耐力と壁土の 圧縮強度の関係を図 14 に示す。相関係数 (図 14 の R) から、貫のこ じり抵抗は中塗りよりも荒壁の方が耐力発現に寄与しているといえ る。

壁土を同一として下地の違いのみで比較した［伏見］の試験結果 を図 15 に、試験結果の最大耐力の比較を図 16 に示す。荒壁の乾燥 収縮による初期すべりにより初期変形時の挙動はばらつくので、最 大耐力付近以降の挙動で比較してみると、小舞の種類 $[\mathrm{A}]$ と小舞 の幅と間隔 $[\mathrm{E}$ ］以外では、すべての試験体において［基準］とほぼ 同じような挙動を示した。小舞の種類 $[\mathrm{A}]$ では A4 のみ [基準 $]$ と 比較して耐力が低かったが、[荒木田］と［播磨］を見てみると(図 17)、[荒木田］では $\mathrm{A} 2$ と A 3 が [基準］と比較して耐力が高く、[播磨］ では寸べて [基準］と同じような挙動を示している。よって、A2 と A3 では、[伏見］と［播磨］で［基準］と同じような挙動を示しており、
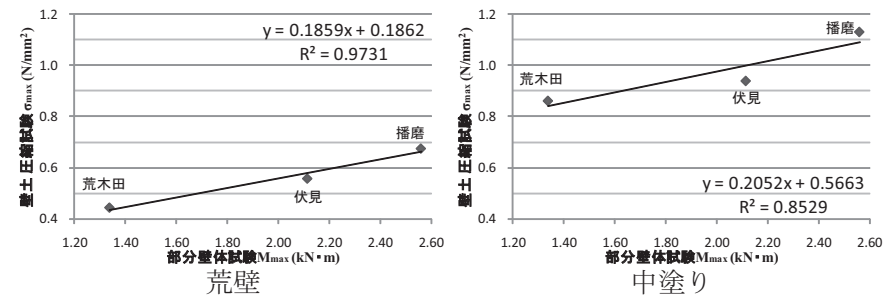

図 14 貫のこじり部分壁体試験［基準］の最大耐力と壁土強度の関係 


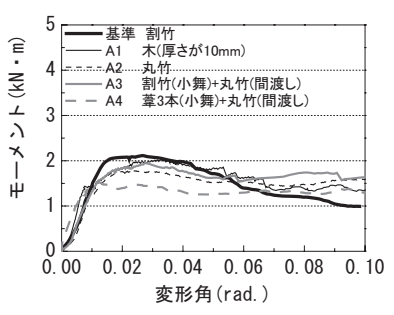

小舞の種類 $[\mathrm{A}]$

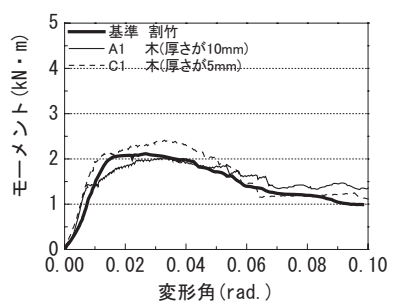

小舞の厚さ $[\mathrm{C}]$

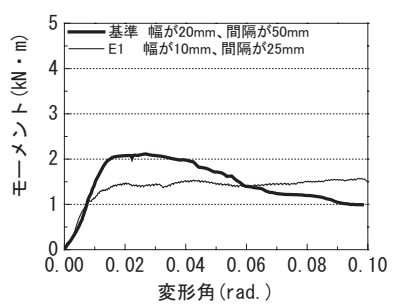

小舞の幅と間隔 $[\mathrm{E}]$

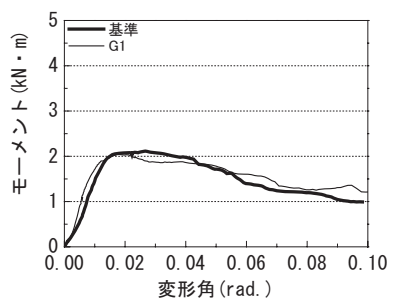

地貫と横架材の間隔 $[\mathrm{G}]$

図 15 貫のこじり部分壁体試験結果 [伏見］(下地比較)

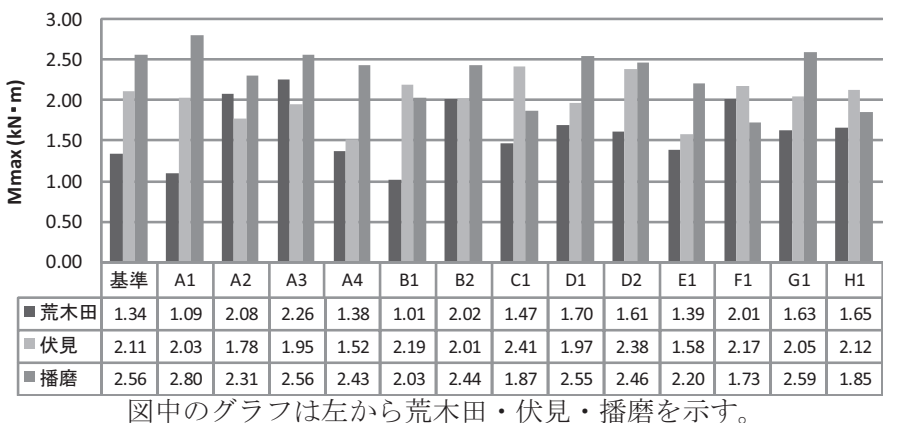

図 16 貫のこじり部分壁体試験結果の最大耐力の比較

A4 では、［荒木田］と［播磨］で［基準］と同じような挙動を示し ているので、 1 体だけばらついたとして下地の違いによる影響は少 ないと判断できる。また、小舞の幅と間隔［E］では［基準］と異な る挙動を示したが、[荒木田］と［播磨］を見てみると(図 18)、[基準］ と同じような挙動を示しているので、1 体だけばらついたとして下 地の違いによる影響は少ないと判断できる。[荒木田］と［播磨］に 関しても、荒壁の乾燥収縮による初期すべりにより初期変形時の挙

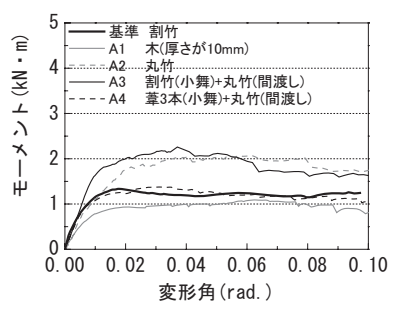

[荒木田］

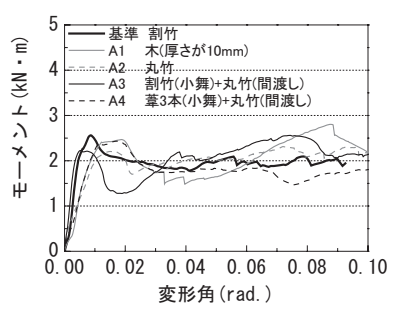

[播磨］
図 17 貫のこじり部分壁体試験結果 (下地比較) 小舞の種類 $[\mathrm{A}]$

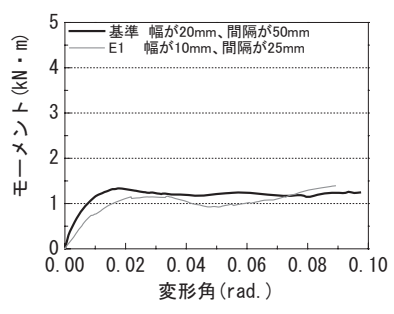

[荒木田]

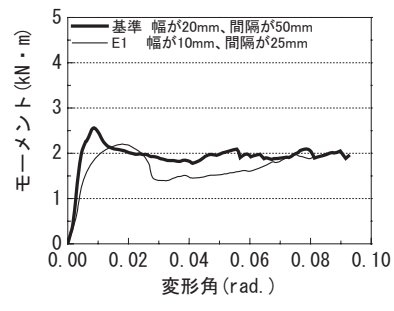

[播磨]
図 18 貫のこじり部分壁体試験結果 (下地比較 ) 小舞の幅と間隔 $[\mathrm{E}]$

動はばらつき、最大耐力以降の挙動は図 15 の［伏見］と同じように、 小舞の種類 $[\mathrm{A} ＼mathrm{~ ） 以 外 て ゙ は ［ 基 準 ］ と 同 し ゙ よ う な 挙 動 を 示 し た 。 ~}$

これらのことより、貫のこじりによる圧縮抵抗は、荒壁の圧縮強 度が大きく影響し、下地の影響は少ないと判断できる。

\section{7. 純せん断部分壁体試験体}

\section{1 試験体の破壊状況}

試験体の破壊状況を写真 5 に示寸。初期段階では、隅角部の圧壊 が見られ、その後、2 種類の破壞モードが確認された。ひとつは、 壁体中央部付近の表面に放射状のせん断ひび割れが入り、試験体の 変形増大に従い土壁の中心から中塗り土が剥離していく破壊 $($ 破壞 c)であり、荒木田と伏見で多く見られた。他方は、壁土の中塗り土

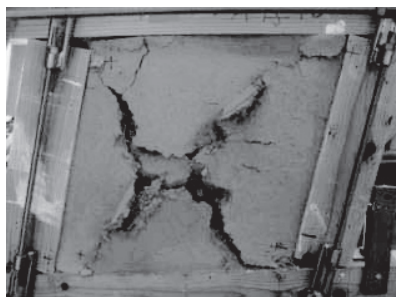

破壊 $\mathrm{a}$

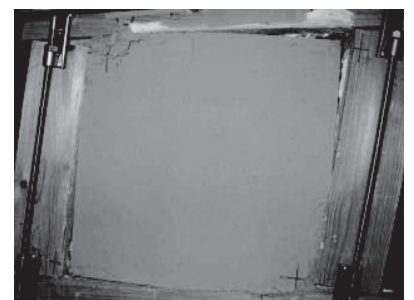

破壊 b
写真 5 隅角部圧縮部分壁体試験体の破壊状況

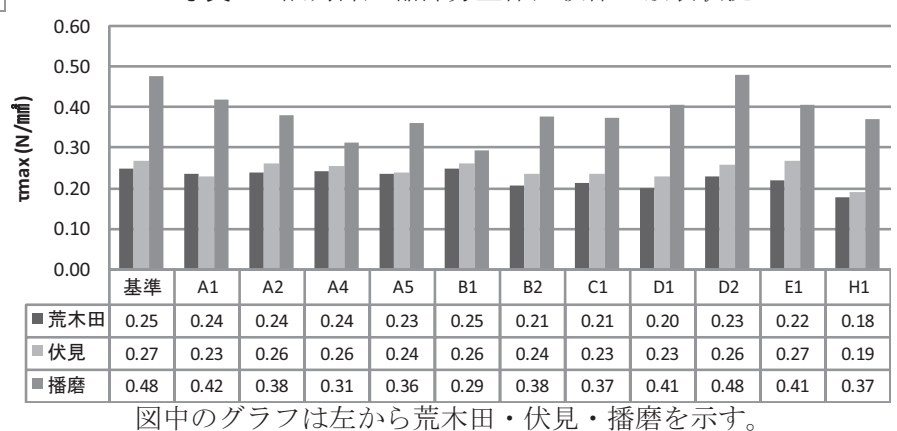

図 19 純せん断部分壁体試験結果の最大耐力の比較 

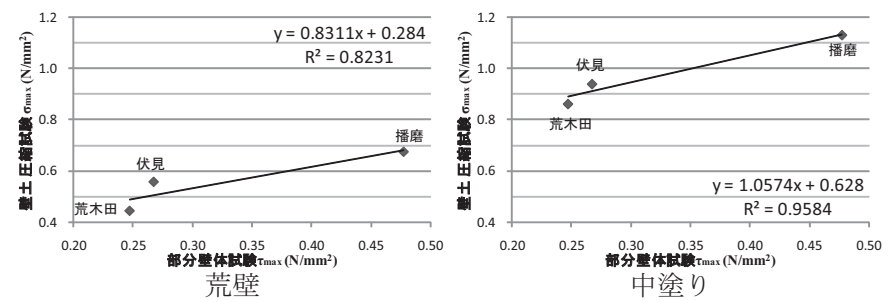

図 20 純せん断部分壁体試験体［基準］の最大せん断応力度と壁土強 度の関係

中央部分にせん断ひび割れは全く入らず、周辺部から中塗り土が徐々 に剥離していく破壊 (破壊 d) であり、播磨で多く見られた。

\section{2 試験結果の比較}

各試験体の最大耐力の比較を図 19 に示す。また、[基準］の最大 せん断応力度と壁土の圧縮強度の関係を図 20 に示す。試験結果は壁 土の圧縮強度と同じように荒木田 $\rightarrow$ 伏見 $\rightarrow$ 播磨の順で高い結果と なった。また、相関係数 (図 20 の R) から、せん断抵抗は若干では あるが荒壁よりも中塗りの方が耐力発現に寄与しているといえる。 仕様の違いによるせん断強度の差は、播磨では仕様の違いによる強 度の影響が確認できたが、荒木田と伏見では、ほとんど確認できず、 壁厚が厚い場合 $[\mathrm{H} 1 ］$ のみせん断強度が低くなった。壁厚が厚い場 合 [H1］では、荒壁のみが［基準］より $20 \mathrm{~mm}$ 厚いだけなので、圧 縮強度の低い荒壁の割合が増え、全断面で応力度換算することによ りせん断強度が低い結果となった。また、播磨では中塗りの剛性が 高く、中塗りのせん断力負担が高いため、中塗りの隅角部の圧壊後に、 荒壁のせん断変形に中塗りが追従できず、荒壁と中塗りの境界面で 付着応力度の大きい周辺部から剥離が生じたと考えられる。このよ うな破壊が生じる原因としては、小舞は軸材に差し込まれて石亳で 固定されており、小舞は軸材と同じように変形していくため、隅角 部が圧壊した後の大変形時に中塗りに作用するせん断力は、小舞を 介して荒壁に伝わり、荒壁から中叙りに付着力を介して伝わってい たためと考えられる。そのため、小舞の間隔が同じ場合、小舞の断 面が大きい(播磨の $[\mathrm{A} 2] \rightarrow[\mathrm{A} 1] \rightarrow[$ 基準 $]$ ) ほどせん断強度が 高くなった。また、小舞の目透かし面積 (小舞間で表と裏の荒壁が つながっている部分の面積) が広い方が荒壁の表と裏との一体性は

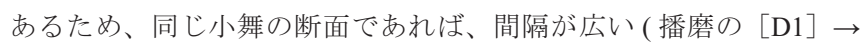
[基準 $] \rightarrow[\mathrm{D} 2])$ ほどせん断強度は高くなった。小舞の断面積比が 同じ (播磨の [基準］と［E1］) 場合、目透かし面積が小さい方がせ ん断強度は低くなった。

これらのことより、純せん断部分壁体試験体から得られた土壁の せん断強度は、壁土の強度が低いときには下地の影響が少なく、壁 土の強度が高い場合には下地の影響が現れることがいえる。

\section{8. 部分壁体試験結果から推算した 1P 耐力壁の比較}

隅角部圧縮部分壁体試験体と貫のこじり部分壁体試験体の試験結 果から部分壁体試験体の想定壁長である $1 \mathrm{P}$ 耐力壁の水平せん断力ー 変形角関係を 3.2 節の方法で推算し、下地を同一として 3 種類の壁 土で比較した [基準］の $1 \mathrm{P}$ 耐力壁の比較を図 21 に示寸。文献 3)の 『比較実験』で得られた各耐力要素の負担割合の推移 (図 7) によると、 $0.01 \mathrm{rad}$ 付近までは隅角部の圧縮抵抗が支配的であるが、0.01 rad 以降
では貫のこじり抵抗が支配的になる。［基準］の1P 耐力壁も同じよ うに、変形角が $0.01 \mathrm{rad}$ 付近までは隅角部圧縮部分壁体試験体の試験 結果と同じような挙動となり、[播磨］の耐力が非常に高く、[荒木田］ と［伏見］は同じような結果になったが、変形角が $0.01 \mathrm{rad}$ 以降にな ると貫のこじり部分壁体試験体の試験結果と同じような挙動を示し、 ［伏見］と［播磨］は同じような結果になったが、[荒木田］の耐力 は低い結果となった。また、[基準］以外の 1P 耐力壁では、各下地 について 3 種類の壁土で比較してみても [基準］と同じような結果 となった。

壁土を同一として下地の違いのみで比較した［伏見］の $1 \mathrm{P}$ 耐力壁 を図 22 に示す。貫のこじり部 分壁体試験体ではすべての試験 体において［基準］とほぼ同じ ような挙動を示したので、1P 耐 力壁で比較してみると貫間距離 [F] 以外は隅角部圧縮部分壁体 試験体と同じ結果となった。ま た、 5 段貫 $[\mathrm{F} 1]$ のみ貫の本数

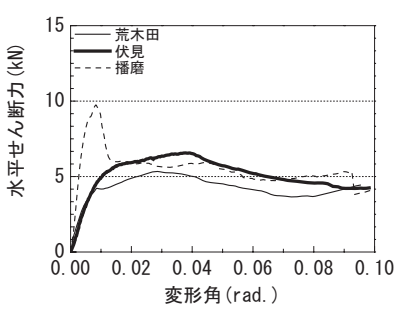

図 21 1P 耐力壁 [基準

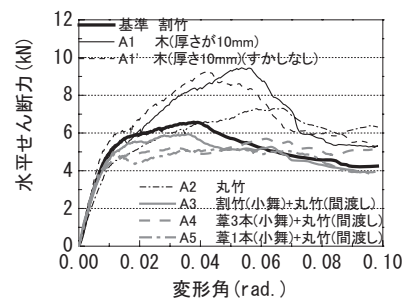

小舞の種類 $[\mathrm{A}]$

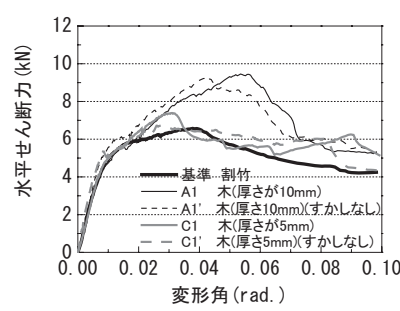

小舞の厚さ $[\mathrm{C}]$

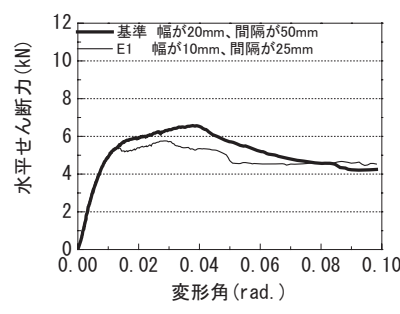

小舞の幅と間隔 $[\mathrm{E}]$

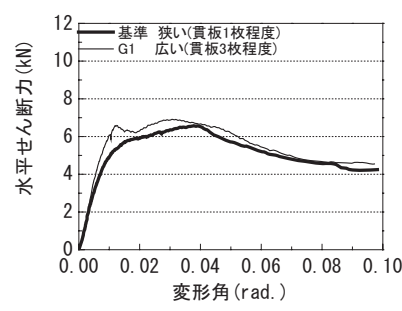

地貫と横架材の間隔 [G] 図 22 1P 耐力壁の推算值 [伏見］(下地比較)

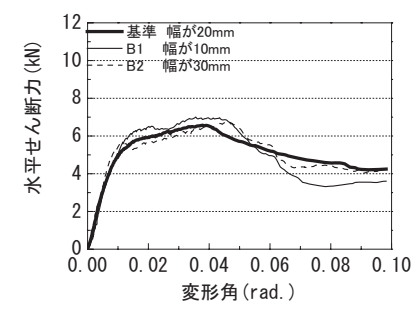

小舞の幅 $[\mathrm{B}]$

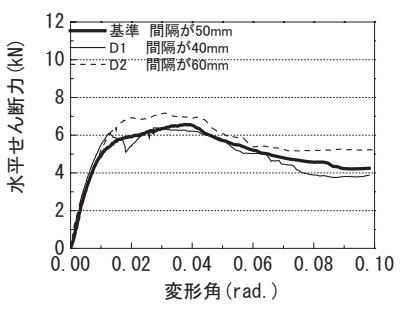

小舞の間隔 $[\mathrm{D}]$

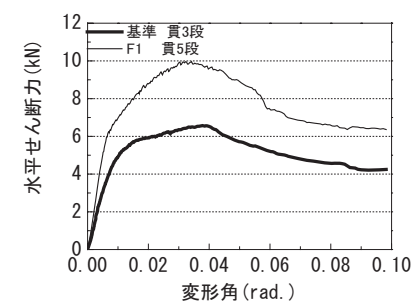

貫間距離 $[\mathrm{F}]$

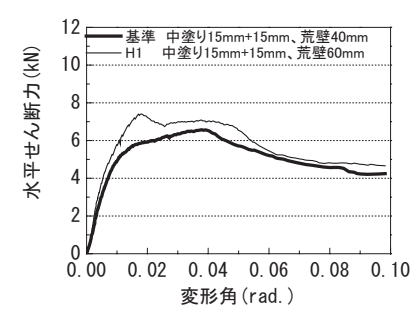

塗り厚が異なる壁体 $[\mathrm{H}]$ 
が 2 本分多くなるので、貫の耐力分だけ［基準］より耐力が高くな った。［荒木田］と［播磨］に関しても、変形角が $0.01 \mathrm{rad}$ 付近まで は隅角部の圧縮抵抗が支配的であるので図 20 の [基準］と同じよう な挙動となり、変形角が $0.01 \mathrm{rad}$ 以降になると 3 種類の壁土の違いに よる強度の差は見られず、図 22 の[伏見］と同じような挙動となった。

\section{9. まとめ}

本論文では、全国各地で行われている様々な施工方法や使用材料 の調査結果に基づき実験変数を定めて、力学モデルに基づいて土壁 の抵抗機構を評価するために開発された部分壁体試験体を用いて実 験的調査を行った。仕様の相違が土壁の構造性能に及ぼす影響を、 壁土の種類が異なっても各種下地の影響は同じように現れると仮定 して、壁土を 3 種類かえて各実験変数に対して 1 体ずつ実験を実施 した。各種下地の影響に関する比較は、同一の下地による 3 種類の 壁土の傾向から総合的に判断した。その結果、抵抗機構毎に得られ た知見を以下に要約する。

(1)隅角部の圧縮抵抗に関しては、0.01 rad 付近までは主として壁土の 圧縮により抵抗しており、荒壁よりも中塗りの方が耐力発現に寄与 している。0.01 rad 以降では主として下地の圧縮により抵抗しており、 間渡しの仕様が同じで小舞の幅や小舞の間隔の違いによる実験変数 では、同じようなモーメントー変形角関係を示し、強度の差は見ら れなかったことから、下地の圧縮抵抗では間渡しの強度負担の割合 が高いことがわかった。また、間渡しの圧縮強度は、仕様の違いで 比較すると、[葦 $(1$ 本 $)] \rightarrow[$ 蔁 $(3$ 本 $)] \rightarrow[$ 割竹 $] \rightarrow[$ 丸竹 $] \rightarrow[$ 木 (厚さ $10 \mathrm{~mm})$ ）の順で耐力が高く、厚みで比較すると、厚い方が耐 力が高かった。

(2)貫のこじりによる圧縮抵抗に関しては、中塗りよりも荒壁の圧縮 強度が大きく影響しているため、初期変形時では荒壁の乾燥収縮の 度合により初期すべり量が異なった。また、使用材料や下地の組み 方など相違による影響は少ないことがわかった。

(3)土壁のせん断強度に関しては、壁土の強度が低いときは下地の影 響が少なく、壁土の強度が高い場合には使用材料や下地の組み方な ど相違による影響が見られた。壁土の強度が高い場合の使用材料や 下地の組み方など相違による影響は、小舞の間隔が同じ場合、小舞 の断面が大きいほどせん断強度が高く、小舞の目透かし面積 $($ 小舞 間で表と裏の荒壁がつながっている部分の面積 ) が広い方が荒壁の 表と裏との一体性はあるため、同じ小舞の断面であれば、間隔が広 いほどせん断強度は高く、小舞の断面積比が同じ場合、目透かし面 積が小さい方がせん断強度は低かった。また、壁土の相違で比較し てみた結果、せん断抵抗は若干ではあるが荒壁よりも中塗りの方が 耐力発現に寄与しているということがわかった。

(4) 1P 耐力壁 (幅 $910 \mathrm{~mm}$ ) に関しては、0.01 rad 付近までは、隅角部の 圧縮抵抗が支配的であるので、隅角部圧縮部分壁体試験体の試験結 果と同じような挙動となる。0.01 rad 以降では、貫のこじりによる圧 縮抵抗は使用材料や下地の組み方など相違による影響は少ないため、 隅角部圧縮部分壁体試験体の試験結果と同じような挙動が見られた。 よって、使用材料や下地の組み方など相違による影響は、隅角部の 圧縮抵抗と同じように間渡しの圧縮強度によるものが大きいことが わかった。しかし、1P 耐力壁の比較では、せん断破壊しないものと して比較しているため、せん断破壊する場合の壁長が長い耐力壁で
は、土壁の最大耐力が土壁のせん断強度と同じような下地の影響が 見られると考えられる。

今後は、部分壁体試験で得られた播磨のように、中塗りの強度が 高い場合の挙動が他と異なっており、その傾向が実大の土壁でも現 れるか検証する必要がある。

\section{参考文献}

1) 三芳紀美子、大橋好光 : 土壁の強度に関する研究 その 2 実大面内せん断 試験、日本建築学会大会学術講演梗概集＼cjkstart構造III、C-1、pp.409-410、2003.9

2) 村上雅英、景山誠、鈴木有、稲山正弘：静的水平加力実験に基づく土壁の 而荷機構の解明一せん断破壊しない土壁の力学挙動一、日本建築学会構造系 論文集、第 582 号、pp.103-108、2004.8

3) 村上雅英、景山誠、岡本滋史、鈴木有、稲山正弘：要素試験による土壁の 水平力耐荷機構の検証 - せん断破壊が先行しない土壁の力学挙動 (続)-、日 本建築学会構造系論文集、第 594 号、pp.111-118、2005.5

4) 村上雅英、景山誠、岡本滋史、鈴木有、稲山正弘：水平力の耐荷機構に基 づく土壁の剛性と耐力の算定法に関寸る提案と検証、日本建築学会構造系論 文集、第 605 号、pp.119-126、2006.7

5) 澤田圭、岡本滋史、村上雅英、川鍋亜衣子、鈴木有：耐荷機構に基づく 有開口土壁の剛性と耐力の推定、日本建築学会構造系論文集、第 620 号、 pp.pp.93-100、2007.10

6) 岡本滋史、澤田圭、村上雅英、鈴木有、稲山正弘：部分壁体試験に基づく 土壁のせん断力ー変形角関係及び壁倍率の推定方法と検証、日本建築学会構 造系論文集、第621 号、pp.103-110、2007.11

7) 山田耕司 : 壁土強度のばらつきの土壁耐力への影響、日本建築学会構造系 論文集、第 620 号、pp.87-92、2007.10

8) 中尾方人、山崎裕：土塗り壁の耐力および変形性能の推定に関する実験的 研究その 9 真壁形式の土塗り壁工法に関するアンケート調査、日本建築 学会大会学術講演梗概集、C-1、pp.237-238、2007.8

（2008年10月27日原稿受理，2009年 4 月13日採用決定） 